\title{
Vakum Tüplü Solar Kolektörler için Ekonomik Kaplama Malzemesi ve Kaplama Metodu
}

\section{Economical Coating Material and Method for Vacuum Tube} Solar Collectors

\author{
Çınar Öncel 1 10 \\ ${ }^{1}$ Muğla Sıtkı Koçman Üniversitesi Mühendislik Fakültesi Metalurji ve Malzeme Mühendisliği, Muğla, TÜRKiYE \\ Sorumlu Yazar / Corresponding Author* : cinaroncel@mu.edu.tr

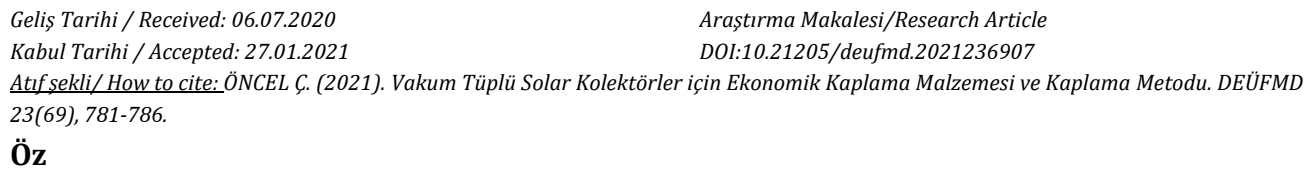

Vakum tüplü güneş enerjisi sistemlerinde DC magnetron saçılımı metodu ile cam tüp üzerine aluminyum ve aluminyum nitrür kaplaması yapılmaktadır. Bu kaplama, gelen güneş ışınının \%96 civarını soğurmakta (\%4 civarını yansıtmaktadır) ve dıştaki cam tüp ile arasında vakum olduğu için ısının tamamına yakınının iç cam tüpün içerisine iletmektedir. Bu kaplama malzemesinin özelliği, hem gelen güneş ışığının çok azını geri yansıtması, hem de ısı iletkenlik değerinin yüksek olmasıdır. $\mathrm{Bu}$ çalışmada kaplama malzemesine ve magnetron saçılımı kaplama metoduna alternatif olarak, çeşitli kaplama malzemeleri ile, püskürtme ve daldırma-kaplama metodları ile çalışılmıştır. Yapılan çalışmalar, daldırma-kaplama metodu ile yapılan grafit kaplamanın, ticari aluminyum nitrür kaplamalı vakum tüplü sistemlerin veriminin \%67'si kadar verime ulaştığını göstermiştir. Bu kaplamanın yüzey tutunma özelliğinin arttırılarak, pahalı ekipmanlarla uygulanan DC magnetron saçılımı metodu olmadan, yeni nesil vakum tüplü solar kollektörler üretilebileceği gösterilmiştir.

Anahtar Kelimeler: grafit, vakum tüplü solar kollektör, kaplama metodu

\begin{abstract}
In vacuum tube solar collectors aluminum and aluminum nitride coating is conducted via DC magnetron sputtering. This coating absorbs $96 \%$ of the incoming solar energy and since there is vacuum between outer and inner glass tubes, almost all of the heat is transferred into the inner tube. The characteristics of the coating material is to reflect very few amount of incoming waves and to possess high thermal conductivity. In this study, several alternative coating materials and coating techniques such as dip coating and spray coating. The results showed that graphite coating via dip coating method could reach $67 \%$ of the commercial aluminum nitride coated vaccum tube systems. By increasing the surface adhesion of the graphite with dip coating showed that the results of this study may replace currently used DC magnetron sputtering technique and eliminate expensive equipments to take place in new generation vacuum tube solar collectors.

Keywords: graphite, vacum tube solar collector, coating method
\end{abstract}




\section{Giriş}

Vakum tüplü güneş enerjisi sistemleri, iki adet iç içe geçmiş ve arası vakuma alınmış cam tüplerden, içteki camın dış yüzeyine ısı iletkenliği ve ışın yansıtma kapasitesi düşük bir kaplama ile kaplı, vakum alındıktan sonra "degassing" yapmak için ve vakumun sağlamlığını kontrol etmek için bir adet barium halkası ve barium halkasının aktive edildikten sonra oluşturduğu barium aynası, genellikle kullanılan isı pompasından ve su deposundan ibarettir. Şekil 1'de ISı pompası ve su deposu dışındaki bileșenler temsili olarak gösterilmiștir.

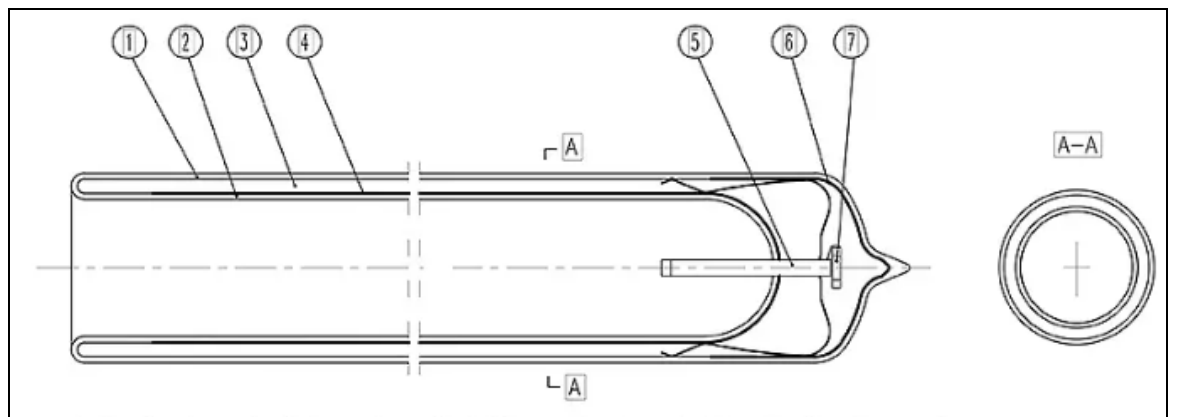

Şekil 1. Vakumlu cam tüpün șematik görüntüsü. 1-dış cam tüp, 1-iç cam tüp, 3-vakumlu bölge, 4-ısı soğuran ve ileten kaplama, 5-baryum halkasını sabit tutmak için metal ayaklar, 6-oluşan baryum aynası, 7- baryum halkası

Vakumlu tüpler üretilirken DC magnetron saçılımı ile en yaygın kullanılan, içteki tüpün üzerine alüminyum ve alüminyum nitrür kaplaması yapılır[1-4]. $\mathrm{Bu}$ kaplamanın soğurduğu enerji, gelen enerjinin \%96's civarındadır[5]. İki tüpün arasındaki vakumdan ve kaplamanın yüksek oranda enerji soğurmasından dolayı güneşten gelen ısının büyük kısmı içteki tüpün içine transfer edilebilmektedir. Bu tekniğin temelleri 1900'lü yılların bașlarına dayanmaktadır[6]. DC magnetron saçılımı ile kaplama işlemi vakum gerektiren ve yüksek enerji tüketen bir işlemdir. $\mathrm{Bu}$ kaplamanın alternatif ve doğa dostu bir kaplama ile yapılması hem maliyeti düşürecek, hem de enerji gereksinimini azaltan faydaları olacaktır. $\mathrm{Bu}$ alandaki çalışmalar genellikle kaplama metodu aynı kalacak şekilde, farklı malzeme veya malzeme grupları ile kaplamalar üzerindedir[2,5,7-9].

Ayrıca kaplama malzemesi olarak farklı malzemeler de denenebilir. $\mathrm{Bu}$ çalıșmada kaplama metodu olarak püskürtme-kaplama ve daldırma-kaplama metodları çalışılmıștır. Kaplama malzemesi olarak da yüksek isı iletkenliğine sahip grafit, hekzagonal bor nitrür $(\mathrm{hBN})$, alüminyum nitrür (AlN) ve silikon karbür (SiC) çalışılmıştır. Bu malzemelerin ısı iletkenlik değerleri; SiC için $270 \mathrm{~W} / \mathrm{mK}$ [10], AlN için $320 \mathrm{~W} / \mathrm{mK}[10], \mathrm{hBN}$ için $\mathrm{x}-\mathrm{y}$ yönlerinde $121 \mathrm{~W} / \mathrm{mK}$, z yönünde $71 \mathrm{~W} / \mathrm{mK}[11]$, grafit için x-y yönlerinde $2000 \mathrm{~W} / \mathrm{mK}, \mathrm{z}$ yönünde 6.5 $\mathrm{W} / \mathrm{mK}[12]$ şeklindedir.

Şekil 2'deki düzenek, kaplaması yapılan ve vakum altına alınan vakumlu tüplerin açı havada iç tüpün içinde ürettiği sıcaklığı ölçmek için kullanılmıștır. Bütün numunelerin ürettiği sıcaklıklar aynı koşullarda ölçülmüștür.

$\mathrm{Bu}$ çalışma, kaplama metodu ve kaplama malzemesi değiștirilerek vakum tüplü solar kolektör üretimi için yapılmıș ilk çalışma olarak değerlendirilebilir. Mevcut kaplama teknolojisinin fiziksel sınırlamalarından dolayı iç tüpün sadece dış yüzeyi kaplanabilirken, kaplama metodunun değiştirilmesinden kaynaklı olarak iç tüpün iç yüzeyinin de kaplama alanı olarak kullanılması söz konusu olacaktır. Bu durum bir sonraki çalışma konusu olacaktır.

\section{Materyal ve Metod}

Bu çalışmada iki farklı kaplama metodu ve dört farklı kaplama malzemesi kullanılmıștır. Bunlar püskürtme-kaplama ve daldırma-kaplama metodlarl, grafit, hBN, AlN ve $\mathrm{SiC}$ şeklindedir. Püskürtme-kaplama metodunda cam tüp döndürme hızı olarak $200 \mathrm{rpm}$ seçilmiş, kaplama süreleri olarak 120 saniye, 20 saniye ve 10 saniye kullanılmıştır. Daldırma-kaplama metodunda çözelti içerisinde 1 tur döndürme 
yapılmıştır. Bütün kaplamalardan önce çözelti 240 saniye sonikatörde bekletilmiştir.

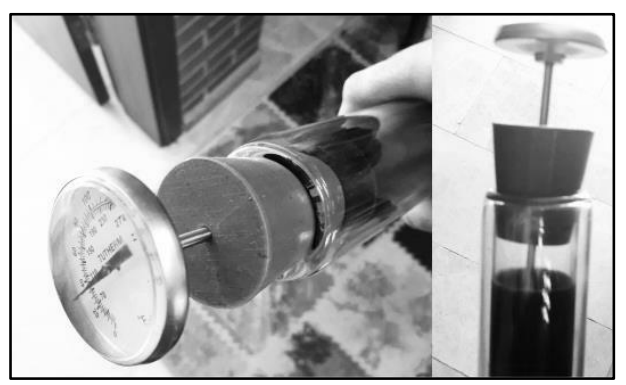

Şekil 2. Kaplaması yapılmış ve vakuma alınmış tüplerin sıcaklık ölçme düzeneği

Kaplama çözeltilerinde toz:kür ajanı:polimer:hekzan oranları Tablo 1'de verilmiştir. İki numunede ise kaplama yapıldıktan ve kurutulduktan sonra $450^{\circ} \mathrm{C}^{\prime}$ de 30 dakika firınlama yapılmış ve sonuçlar karșılaștırılmıștır. Tablodaki kodlardan S, A, B ve G; sirasıyla $\mathrm{SiC}, \mathrm{AlN}$, hBN ve grafit tozları ile yapılan kaplamaları göstermektedir. Ortalama olarak tozların parçacık büyüklükleri; $\mathrm{SiC} 0.8$ mikrometre, AlN 0.5 mikrometre, hBN 1 mikrometre ve grafit 10-20 mikrometre șeklindedir. Grafitin daha küçük boyutta seçilmemesinin sebebi, 10 mikrometre ve daha büyük kristal boyutlarında ISı iletkenliğinin teorik limitlere ulaşabildiğinin rapor edilmesidir[12]. Polimer olarak belirtilen malzeme Slygard 184 kodlu polidimetilsiloksan (PDMS), kür ajanı ise Slygard 184 kür ajanıdır. Çözücü olarak yüksek saflıkta hekzan kullanılmıştır. Kaplamaların ışık soğurma yüzdeleri Solarsan A.Ş. firmasının arge laboratuvarında bulunan optik emilim ve emisyon cihazı ile ölçülmüştür. Deneysel işlemlerle ilgili şematik akış şeması Şekil 3'te gösterilmiştir.

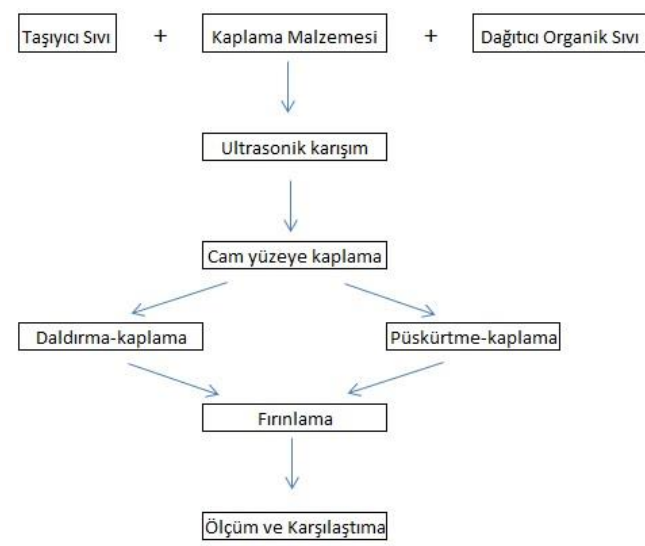

Şekil 3. Deneysel işlemleri gösteren akıș șeması

Tablo 1. Cam tüplere yapılan kaplamaların parametreleri

\begin{tabular}{|c|c|c|c|c|c|c|}
\hline $\begin{array}{c}\text { Numune } \\
\text { Kodu }\end{array}$ & $\begin{array}{l}\text { Kaplama } \\
\text { Metodu }\end{array}$ & $\begin{array}{l}\text { Cam Tüp } \\
\text { Döndürme Hızı }\end{array}$ & $\begin{array}{l}\text { Kaplama } \\
\text { Süresi }\end{array}$ & $\begin{array}{l}\text { Sonikatör } \\
\text { Süresi }\end{array}$ & $\begin{array}{c}\text { Toz-Kür ajanı-Polimer- } \\
\text { Hekzan miktraları }\end{array}$ & $\begin{array}{l}\text { Fırınlama } \\
\text { sıcaklıĕı }\end{array}$ \\
\hline G1 & Daldirma & 1 tur döndürme & 10 saniye & 240 saniye & $67.5 \mathrm{gr}-1.38 \mathrm{gr}-13.8 \mathrm{gr}-190 \mathrm{ml}$ & $450^{\circ} \mathrm{C}-30 \mathrm{dK}$ \\
\hline G1 & Daldirma & 1 tur dondurme & 10 saniye & 240 saniye & $67.5 \mathrm{gr}-1.38 \mathrm{gr}-13.8 \mathrm{gr}-190 \mathrm{ml}$ & yopelmadi \\
\hline$\$ 1$ & Püskürtme & $200 \mathrm{rpm}$ & 120 saniye & 240 saniye & $2 \mathrm{gr}-0.05 \mathrm{gr}-0.5 \mathrm{gr}-50 \mathrm{ml}$ & yapelmadi \\
\hline$\$ 2$ & Püskürtme & $200 \mathrm{rpm}$ & 20 saniye & 240 saniye & $4 \mathrm{gr}-0.1 \mathrm{gr}-1 \mathrm{gr}-75 \mathrm{ml}$ & Yapelmadı \\
\hline$\$ 3$ & Daldirma & 1 tur dondurme & 10 saniye & 240 saniye & $18 \mathrm{gr}-0.4 \mathrm{gr}-4 \mathrm{gr}-75 \mathrm{ml}$ & $450^{\circ} \mathrm{C}-30 \mathrm{dk}$ \\
\hline$\$ 3$ & Daldirma & 1 tur dondurme & 10 saniye & 240 saniye & $18 \mathrm{gr}-0.4 \mathrm{gr}-4 \mathrm{gr}-75 \mathrm{ml}$ & yopelmadi \\
\hline A1 & Daldirma & 1 tur döndürme & 10 saniye & 240 saniye & $67.5 \mathrm{gr}-1.38 \mathrm{gr}-13.8 \mathrm{gr}-190 \mathrm{ml}$ & yapelmadi \\
\hline $\mathrm{A} 2$ & Püskürtme & $200 \mathrm{rpm}$ & 120 saniye & 240 saniye & $6 \mathrm{gr}-0.15 \mathrm{gr}-1.5 \mathrm{gr}-75 \mathrm{ml}$ & yapelmadi \\
\hline 81 & Püskürtme & $200 \mathrm{rpm}$ & 120 saniye & 240 saniye & $4 \mathrm{gr}-0.92 \mathrm{gr}-9.2 \mathrm{gr}-190 \mathrm{ml}$ & yopelmadi \\
\hline$B 2$ & Daldırma & 1 tur döndürme & 10 saniye & 240 saniye & $45 \mathrm{gr}-0.92 \mathrm{gr}-9.2 \mathrm{gr}-190 \mathrm{ml}$ & Yapelmadi \\
\hline 83 & Daldirma & 1 tur dondürme & 10 saniye & 240 saniye & $45 \mathrm{gr}-0.92 \mathrm{gr}-9.2 \mathrm{gr} r-380 \mathrm{ml}$ & yapelmadi \\
\hline
\end{tabular}

Kaplama yapılan cam tüplerin ışığı soğurma kapasiteleri optik soğurma ve yayma spektroskobu ile ölçülmüștür. Bu değerlere göre en iyi sonucu veren numunelerin ürettiği sıcaklık değerleri Şekil 2'deki düzenekle ölçülmüștür. Referans olarak ticari olarak piyasada kullanılan, DC magnetron saçılımı ile kaplanmıș AlN/Al kaplamalı bir tüp kullanılmıştır. Ayrıca bir de kaplama yapılmamıș vakumlu cam tüpün ürettiği sıcaklık ölçülmüştür. Ticari tüplerin ebatları dış tüp için $1800 \mathrm{~mm}$ boy $58 \mathrm{~mm}$ dış çap, iç tüp için 1500 $\mathrm{mm}$ boy, $47 \mathrm{~mm}$ diş çap ve $1.6 \mathrm{~mm}$ cam kalınlığ olacak şekilde ve araları $5 \times 10^{-3} \mathrm{~Pa}$ vakumda olacak şekilde üretilmektedir. 
Tablo 1'deki kodlardan G1 kodlu numuneler, grafit ile kaplanmıș cam tüpün kaplamadan sonra $450^{\circ} \mathrm{C}$ 'de 30 dakika firınlanan ve firınlanmayan numuneleri karşılaştırmak için yapılmıștır. S1 ve S2 numuneleri, SiC ile püskürtme ile kaplanan numunelerin kaplama sürelerinin karşılaștırılması için yapılmıștır. S3 kodlu numuneler daldırma kaplama metodu ile üretilmiștir. Bir tanesi kaplamadan sonra $450^{\circ} \mathrm{C}$ 'de 30 dakika firınlanmış, diğeri firınlanmamıștır. A1 kodlu numune, AlN'nin daldırma kaplama ile kaplanan numuneyi, A2 kodlu numune AlN'nin püskürtme kaplama metodu ile kaplanan numuneyi göstermektedir. B1 kodlu numune, hBN tozlarının püskürtme kaplama metodu ile, B2 ve B3 kodlu numuneler hBN tozlarının daldırma kaplama metodu ile ve farklı hekzan oranları ile kaplanan numuneleri göstermektedir.

\section{Bulgular}

Yapılan güneș ıșını soğurma testlerinden sonra her kaplama malzemesinin farklı koşullardaki ışın soğurma yüzdeleri her örnekten 5 ölçüm ortalaması alınarak karşılaştırılmıștır. Tablo 2'de sonuçlar verilmiștir. Grafitle kaplanan ve sonrasında isıl ișlem uygulanan numunede ortalama \%76 ıșın soğurması gerçekleșirken, ısıl işlem yapılmayan numunede bu oran \%80'e çıkmıștır. Ticari ve DC magnetron saçlımı ile AlN/Al kaplanan numunelerde bu oran \%96 civarında çlkmaktadır. SiC kaplamalı numunelerde farklı koșullara ragmen bütün sonuçlar \%69-\%70 bandında çıkmıștır. AlN tozu ile kaplanan numunelerde ışın soğurma kapasitesi daha da düşmüş, \%56-57 civarında çımıștır. Isı iletkenlik değeri diğerlerine göre daha az olan hBN tozu ile kaplanan numunlerde ise oldukça düșük ısı soğurma kapasitesi (\%8) ile kaşılaşılmıştır. sıcaklık ölçüm deneyleri 3 farklı numune ile yapılmıştır; (i) grafit ile kaplanan numune, (ii) DC magnetron saçılımı ile AlN/Al kaplaması yapılan ticari numune ve (iii) kaplama yapılmamış vakumlu tüp. Yapılan 30 dakikalık ölçümler sonucunda ticari vakumlu tüpün iç sıcaklığg $180^{\circ} \mathrm{C}$ 'ye, grafit kaplı vakumlu tüpün iç sıcaklığ $120^{\circ} \mathrm{C}$ 'ye, kaplamasız vakumlu tüpün iç sıcaklığı da $40^{\circ} \mathrm{C}$ 'ye çıkmıştır. Deneyler sıranındaki hava sıcaklığ $20^{\circ} \mathrm{C}$ olarak kaydedilmiștir. Bu sonuçlardan anlașıldığı üzere daldırma-kaplama yöntemiyle ve belirtilen parametrelerle grafit kaplanan vakumlu tüp, ticari ürünün $60^{\circ} \mathrm{C}$ altında kalmıș, kaplamasız tüpe oranla çok yüksek değer vermiştir.

Grafit kaplı numunelerde bir numne de tüpün içinden kaplama yapılarak deneme yapılmıștır. Çıkan sonuçlar içten veya dıştan kaplamanın sonuçlarda ölçülebilir bir fark yaratmadığı yönündedir. İç tüpün içten ve dıștan kaplı, ticari ve kaplanmamış tüplerin görüntüleri Şekil 4'te verilmiștir.

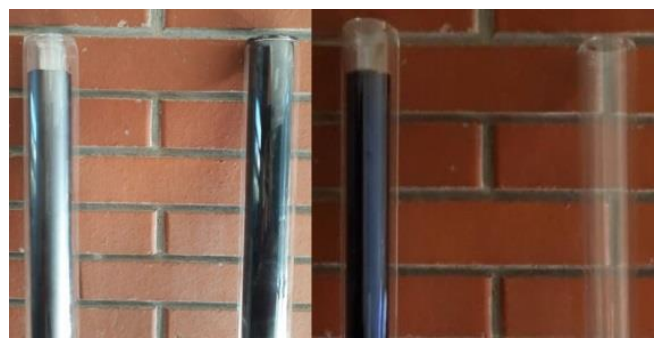

Şekil 4. Soldan sağa sırasıyla dıștan grafit, içten grafit kaplamalı tüpler, ticari tüp ve kaplamasız tüp görüntüleri 
DEÜ FMD 23(69), 781-786, 2021

Tablo 2. Cam tüplere yapılan kaplamaların güneş ışını soğurma deneylerinin sonuçları

\begin{tabular}{|c|c|c|c|c|c|c|c|}
\hline \multirow{2}{*}{$\begin{array}{l}\text { Kaplama } \\
\text { Malzeme }\end{array}$} & \multicolumn{5}{|c|}{ Işın Soğurma Yüzdesi } & \multirow{2}{*}{ Ortalama } & \multirow{2}{*}{$\begin{array}{c}\text { Standart } \\
\text { Sapma }\end{array}$} \\
\hline & Ölçüm 1 & Ölçüm 2 & Ölçüm 3 & Ölçüm 4 & Ölçüm 5 & & \\
\hline $\mathrm{G} 1-450^{\circ} \mathrm{C}$ & 76.1 & 75.9 & 77.4 & 78.3 & 73.7 & 76.28 & 1.56 \\
\hline G1 & 80.7 & 80.9 & 79.9 & 80.4 & 78 & 79.98 & 1.05 \\
\hline S1 & 66.9 & 64.3 & 63.6 & 72.2 & 78 & 69 & 5.42 \\
\hline S2 & 67.7 & 65.4 & 64.6 & 72.5 & 80 & 70.04 & 5.69 \\
\hline S3 & 65.7 & 62.6 & 62.1 & 70.5 & 83.9 & 68.96 & 8.05 \\
\hline $\mathrm{S} 3-450^{\circ} \mathrm{C}$ & 66.4 & 64.1 & 62.8 & 71.2 & 80.2 & 68.94 & 6.32 \\
\hline $\mathrm{A} 1$ & 52.3 & 54.4 & 53.3 & 57.4 & 60.6 & 55.6 & 3.03 \\
\hline $\mathrm{A} 2$ & 54 & 56 & 54.8 & 59.4 & 62.4 & 57.32 & 3.14 \\
\hline B1 & 3.1 & 7.1 & 5.7 & 9.8 & 15.1 & 8.16 & 4.09 \\
\hline B2 & 2.1 & 6.7 & 5.3 & 10 & 16.6 & 8.14 & 4.93 \\
\hline
\end{tabular}

\section{Tartışma ve Sonuç}

hBN için bu kadar düşük değer elde etmemizin sebebi, güneș ıșınlarının yansıtma kapasitesinin yüksek olması olabilir. hBN kristallerinin düşük dalgaboylu UV dalgalarını soğurduğunu, daha büyük dalgaboylarını soğurmadığını rapor eden çalışma bu fikrimizi doğrulamaktadır[13]

AlN ve SiC tozları ile yapılan kaplamaların soğurduğu enerji oranlarının sırasıyla \%56-57 ve \%69-70 olmasının birkaç sebebi olabilir. Bunlardan birisi, hBN'de olduğu gibi ışın yansıtma kapasiteleri, diğeri ise tozların cam yüzeyi ile yaptıkları toplam kontakların yüzey alanının düşüklüğü olabilir. DC magnetron saçılımı ile yapılan AlN kaplamasında \%96 ıșın soğurması, hem kaplamanın toz kaplamaya göre daha yüksek yüzey alanı olușturması, hem de AlN kaplamasının altında çok yüksek (neredeyse \%100) infrared dalgaboyunu yansıtması olabilir. Vakum ile $\mathrm{Al}$ arasında kalan AlN kaplaması, Al'den yansıyan IR ile daha da fazla isınacaktır.

Bütün numunelerde en yüksek değer olarak \%80 ıșın soğurma kapasitesi gösteren grafit kaplı numunelerin 2 eksendeki çok yüksek ısı iletklenliğinin bu performansın en önemli etkisi olduğu düşünülmektedir. Ayrıca seçilen parçacık büyüklüğü de grafitin teorik limitlerine yakın kapasitesini kullanmamıza yardımcı olmuș olabilir.

$\mathrm{Bu}$ sonuçlardan sonra grafit kaplamanın performansının iyileştirilmesi ve ticari ürün ile aynı sıcaklık değerini sağlaması için bazı çalışmalar yapılabilir. Bunlardan biri, grafitin cam yüzeyine temas ettiği alanı arttırmaktır. $\mathrm{Bu}$ şekilde sistemin performansının artacağ düşünülmektedir. Ayrıca ticari üründe olan Al yansıtıcı yüzey de eklenirse bu yüzden de bir performans artışı beklenmektedir. Bu çalıșmalar, șu anda devam eden TÜBİTAK projemizin konusudur ve çalışmalarımız devam etmektedir.

Sonuç olarak iki farklı kaplama yöntemi ve dört farklı kaplama malzemesi ile yapılan vakumlu tüp performans denemelerinde daldırmakaplama ve püskürtme-kaplama metodları arasında belirgin bir farka rastlanmamıștır. Kaplama malzemesi olarak kullanılan grafit, hBN, AlN ve SiC arasından en yüksek ışın soğurma kapasitesi grafit kaplamalı tüplerde \%80 olarak gerçekleşmiştir. Kaplama yapılan numunelerde kaplama sonrası isıl ișlem yapılmayan numuneler ile yapılan numuneler arasında büyük farklılık görülmemiștir. Grafit kaplı numunelerde ısıl işlem yapılmayan numune, ısıl işlem yapılan numuneye göre daha fazla ıșın soğurma kapasitesi göstermiștir.

Grafit kaplı vakumlu tüplerin $20^{\circ} \mathrm{C}$ ortam sıcaklığında açık havada ve 30 dakikada ürettiği sıcaklık $120^{\circ} \mathrm{C}$ olarak rapor edilmiş, bu değerin arttırılması ve ticari ürünün performansını yakalaması için çalışma önerileri sunulmuştur. Kaplama kalınlığı ile ilgili bir çalışma yapılmamıștır. Kaplama kalınlığının sonuçları etkileyebileceği ve optimum kalınlığın bulunabileceği düşünülmektedir, dolayısıyla bir sonraki çalışmada incelenmesi gereken konulardan birisidir.

Daldırma-kaplama metodu ile grafit kaplanarak üretilecek vakumlu tüplerin, DC magnetron saçılımı ile üretilen vakumlu tüplere göre çok daha düşük maliyetlerle ve daha doğa dostu şekilde üretilebileceği, çalışmanın geliştirilmesi 
DEÜ FMD 23(69), 781-786, 2021

gerektiğinin en büyük göstergesi olarak tespit edilmiștir.

\section{Teşekkür}

$\mathrm{Bu}$ çalıșma, TÜBİTAK tarafından 2150428 numaralı TEYDEB 1512 programı desteği ile fonlanmıștır.

\section{Kaynakça}

[1] Y. Shi, X. Yang 1999. Selective absorbing surface for evacuated solar collector tubes, Renew. Energy. Cilt 16, s. 632-634. doi:https://doi.org/10.1016/S09601481(98)00240-7.

[2] Y. Zhiqiang, G.L. Harding 1984. Optical properties of d.c. reactively sputtered thin films, Thin Solid Films. Cilt.120, s.81-108. doi:https://doi.org/10.1016/00406090(84)90364-X.

[3] G.L. Harding, Y. Zhiqiang, S. Craig, S.P. Chow 1984 Sputtered solar selective absorbing surfaces based on aluminum and stainless steel composites, Sol. Energy Mater. Cilt.10, s.187-207. doi:https://doi.org/10.1016/01651633(84)90060-1.

[4] S. Hou, Z. Xue, Y. Shi, Z. Yin 1992. Improvements in vacuum collector tubes with graded AI-N/AI absorbing surfaces, in: Proc.SPIE doi:10.1117/12.130490.

[5] Q.-C. Zhang 2000. Recent progress in hightemperature solar selective coatings, Sol. Energy Mater. Sol. Cells. Cilt.62, s.63-74 doi:https://doi.org/10.1016/S09270248(99)00136-1.

[6] N. Selvakumar, H.C. Barshilia 2021. Review of physical vapor deposited (PVD) spectrally selective coatings for mid- and high-temperature solar thermal applications, Sol. Energy Mater. Sol. Cells. Cilt.98, s.1-23. doi:https://doi.org/10.1016/j.solmat.2011.10.028.

[7] Q.-C. Zhang 1997. Direct current magnetron sputtered W-AlN cermet solar absorber films, J. Vac. Sci. Technol. A. Cilt.15, s.2842-2846. doi:10.1116/1.580837.

[8] Q.-C. Zhang 1998. Metal-AlN cermet solar selective coatings deposited by direct current magnetron sputtering technology, J. Phys. D. Appl. Phys. Cilt. 3,1 s. 355-362. doi:10.1088/0022-3727/31/4/003.

[9] Q.-C. Zhang 1998. Stainless-steel-AlN cermet selective surfaces deposited by direct current magnetron sputtering technology, Sol. Energy Mater. Sol. Cells. Cilt.52, s.95-106. doi:https://doi.org/10.1016/S09270248(97)00274-2.

[10] D.D.L. Chung 2001. Materials for thermal conduction, Appl. Therm. Eng. Cilt. 21, s. 1593$1605 . \quad$ doi:https://doi.org/10.1016/S13594311(01)00042-4.

[11] K.C. Yung, H. Liem 2007. Enhanced thermal conductivity of boron nitride epoxy-matrix composite through multi-modal particle size mixing, J. Appl. Polym. Sci. Cilt.106 s.3587-3591. doi:10.1002/app.27027.

[12] G. Fugallo, A. Cepellotti, L. Paulatto, M. Lazzeri, N. Marzari, F. Mauri 2014. Thermal Conductivity of Graphene and Graphite: Collective Excitations and
Mean Free Paths, Nano Lett. Cilt. 14, s. 6109-6114. doi:10.1021/nl502059f.

[13] T.Q.P. Vuong, G. Cassabois, P. Valvin, E. Rousseau, A. Summerfield, C.J. Mellor, Y. Cho, T.S. Cheng, J.D. Albar, L. Eaves, C.T. Foxon, P.H. Beton, S. V Novikov, B. Gil 2017. Deep ultraviolet emission in hexagonal boron nitride grown by high-temperature molecular beam epitaxy, 2D Mater. Cilt.4, s.21023. doi:10.1088/2053-1583/aa604a. 